\title{
A Study on the Factors in the Industrial Cluster of Agricultural Biotechnology Parks
}

\author{
Ridong $\mathrm{Hu} \mathrm{PhD}$ in Economics \\ Institute of Quantitative Economics at Huaqiao \\ University \\ No. 668 Jimei Avenue, Jimei District, Xiamen, \\ Fujian, 361021, China \\ Email: j_rdhu@hqu.edu.cn
}

\author{
Chich-Jen Shieh PhD \\ Institute of Quantitative Economics at Huaqiao \\ University \\ No. 668 Jimei Avenue, Jimei District, Xiamen, \\ Fujian, 361021, China \\ Email: charleshieh@hqu.edu.cn \\ (Corresponding author)
}

\begin{abstract}
The research standard of domestic agricultural biotechnology is high and broad, while the industrialization speed is far behind the research standard. In order to accelerate the development of agricultural biotechnology industry, "agricultural biotechnology parks" which present R\&D processing \& marketing and operation functions are planned to rapidly form agricultural technology industrial clusters and accelerate the development of agricultural technology. Experts in agricultural biotechnology parks are analyzed in this study. Total 150 copies of questionnaire are distributed and 102 valid copies are retrieved, with the retrieval rate $68 \%$. The research results sequence the importance of "Level 2" evaluation standards as "technology and knowledge resource", "public infrastructure", "government", "human resource", "financial resource", and "supportive industry". Among 21 evaluation indices, top 5 emphasized indices contain technological innovation, R\&D facilities, training institutions, network information service, and R\&D incentive. Based on the research result, suggestions are proposed in this study, expecting to rapidly form agricultural technology industrial clusters, accelerate the development of agricultural technology, and expand high value-added product export to catch up with advanced countries with agriculture.
\end{abstract}

Key words-government, human resource, public infrastructure, supportive industry, technology

\section{INTRODUCTON}

High value-added and knowledge-oriented industries are currently promoted and developed in Taiwan. In order to develop agricultural technology, the government links the agricultural technology "industrial cluster", which presents mutual correlations of commonality and complementarity, to enhance the transformation of agriculture industry. Domestic agricultural biotechnology presents high and broad research standard, but the industrialization speed is far behind the research standard. In order to accelerate the development of agricultural biotechnology industry, "agricultural biotechnology parks" with R\&D processing \& marketing and operation functions are planned to rapidly form agricultural technology industrial clusters, accelerate the development of agricultural technology, and expand the high value-added product export, expecting to catch up advanced countries with agricultural biotechnology industry.

As biotechnology industry is gradually emphasized by governments in various countries, biotechnology prefectures are rapidly established to result in fierce competition in the future environment. When biotechnology prefectures are massively constructed for biotechnology industry, it is extremely important for the government, the main force to support the industry, applying limited resources. Nonetheless, it is concerned how to avoid overinvestment or scattered resources, i.e. how government departments apply limited resources to key factors for establishing agricultural biotechnology parks different from other technology parks to further create the competitive advantage. For this reason, key success factors in the industrial cluster of agricultural biotechnology parks are discussed in this study.

\section{MATERIAL AND METHODS}

\section{A. Literature review}

1) Agricultural biotechnology

Kong (2012) regarded the development potential of biotechnology for promoting and developing high value-added and knowledge-oriented industry domestically. The so-called "biotechnology" refers to producing products with living organisms or the biological cells, biological process, and metabolites, or getting into the molecular level to understand the vital phenomenon for further development and application to relevant product design or the development of technology platform to solve previous problems so as to improve and promote the quality of human life. In terms of technology, it is divided into general and narrow biotechnologies. General biotechnology (or traditional biotechnology) is a technological discipline combining microbiology, zoology, botany, cytology, chemistry, physics, and engineering. Narrow biotechnology (or new biotechnology) refers to newly developed key technologies, such as genetic engineering technology, protein engineering technology, and hybridoma cell technology. The distinctiveness of biotechnology industry is summarized as below (Katz et al., 2011). 1. Raw materials are mainly 
renewable resources: Raw materials used for biotechnology are regenerated in the biological system that the source is sufficient. In addition to the development of new products, existing products with non-renewable resources are the major source, and biotechnology could provide new production methods. 2. Less energy required: The biotechnological process requires less energy than traditional methods that biotechnology offers alternative means for industries which consume more energy. 3. Lower polluting: The introduction of industries would result in pollution. The pollution resulted from the biotechnological process is lower than it with traditional methods and is easily controlled. 4. Necessary senior human resources: Biotechnology, as a knowledge-intensive advanced technology, requires senior technology personnel. The development of biotechnology not only could promote the level of biological industry, but could also cultivate talents and reinforce the application of human resources. 5. High added value of biological products: The product value could be largely enhanced by biologically treating cheap raw materials. It is considered as an effective motive to attract investment. 6. Broad application: Biotechnology is not merely the tool to research life science, but is a potential applied technology with broad application (Katz et al., 2011).

Kong (2012) divided biotechnology into traditional and modern application that the application of agricultural biotechnology also showed traditional and emerging biotechnology. Traditional area contained the combination of traditional breeding, cultivation, detection, epidemic prevention, fertilizer, and pesticide to largely enhance the production and quality of traditional agriculture. Regarding the application of modern emerging biotechnology, the combination of agriculture with medicine, food, and environmental protection could open the new application of agriculture industry and new development directions.

\section{B. Industrial cluster}

Cluster was first proposed by biologists to explain and describe the phenomena of biotic communities in specific environments and the symbiotic relationship in the nature. It was then used in industries to explain the special spatial concentration in the industrial development process. Lai et al. (2014) described "industrial cluster" as a group of enterprises and foundations which were geographically neighbored, mutually correlated in specific domain, and mutually connected with the commonality and complementarity. It was a network formed by a county or city or the entire nation and even associated with neighboring countries. Lai et al. (2014) further regarded industrial cluster as an essential theory for the development of industry. In other words, "industrial cluster was the key source of national economic competitive advantage." In this case, all advanced economy obviously existed in industrial cluster, and the formation of industrial cluster was a basic factor in the economic development. It was also considered that industrial cluster was "the close connection between industries or enterprises allowing the complementary benefits through product or information circulation." Asche \& Bjorndal (2011) defined cluster as the phenomenon of spatial concentration, competition, and cooperation of firms in the same production chain. Navarro (2011) indicated that upstream and downstream firms of some industries set the factories in neighboring areas to form the so-called "cluster phenomenon", aiming to pursue the convenience of order and delivery, manufacturing-marketing matching, co-design, and capacity backup. Besides, being in the same community could have them understand and trust each other to generate positive function. Valiña (2011) pointed out cluster as a group of upstream and downstream industries with close relationship simultaneously appearing on specific locations. Nutreco (2011) regarded cluster as a group of geographically close companies and the correlated institutions locating in a specific industrial area which were associated with similarity and complementarity.

Hsueh \& Tseng (2013) pointed out industrial cluster as the mutual relationship between individual competitiveness and efficiency of firms, which was composed of three dimensions. 1. Supplier-buyer relationship could be examined with input-output relationship. 2. Cooperator-competitor relationship referred to the competition and cooperation relationship on product R\&D. 3. Shared resource relationship referred to the common use of public facilities and research resource. Sharon \& Laura (2011) mentioned that industrial cluster should contain one or more following relations among industrial members. 1. Geographically common location. 2. Formal mutual connection between import and export or buyers and suppliers. 3. Evidence of non-formal cooperation and competition. 4. Share of commercially related local institutions. Alvial \& Adolfo (2012) proposed two major key factors in the outperformance of 9 biotechnology industrial areas (settlements/clusters) in the USA, including 1.firm R\&D capability and 2.measures to reward the commercialization of R\&D outcomes. Yoo \& Zhao (2010) stated that Boston Consulting Group, in the research report on the comparison of biotechnology parks and biotechnology industrial clusters between the USA and Germany, determined 5 key success factors in biotechnology parks and industrial clusters, including R\&D capability, professional manpower with good quality and stable quantity, technology transfer channel, good infrastructure, and sources of capital.

\section{Factor in industrial cluster}

For developing a technology park type of agricultural biotechnology park, Royne et al. (2015) pointed out the key success factors in cluster as 1.high quality human resource, 2.technology and knowledge resource, 3.supportive industry, 4.perfect public infrastructure, 5.financial (capital) resources, and 6.government.

1). Human resource: Nutreco (2011) referred human resource as the maximum applicable population, in total population, to economic activity, or the population with 
working ability. In this case, the number of population could directly determine the amount of human resources. For professional staff, human resource should stress on enhancing value, rather than reducing cost (Antonelli et al., 2011).

2). Technology and knowledge resource: In the research on the technological knowledge characteristics and technology network of biotechnological pharmaceutical factories in Taiwan, Lernoud \& Willer (2014) selected technological knowledge lifecycle, technological knowledge path dependency, technological knowledge complexity, internal project management of a company, cross-department knowledge circulation, and the interaction among academic research units, government units, and firms as the operational variables of technology and knowledge resource and emphasized that biotechnology industry in Taiwan should well utilize the resources of academic research units and develop with small and medium investment.

3). Supportive industry: The international competitiveness between industries, the upstream and downstream industries and the relevant industries are determined by 1.the correlations, competitive advantage, and development between industries and the relevant industries and 2.the structure chain and development of industries and the upstream, midstream, and downstream industries as well as the competitive advantage (Iizuka et al., 2012). The innovation system of a country was composed of universities, public and private research institutions (including national laboratories), and business communities. Universities used to be responsible for the fundamental research, research institutions were in charge of applied research, and business communities, under the guidance of market opportunities, utilized the research results of the previous two to develop new products or new production technologies to satisfy the living demands of humans.

4). Public infrastructure: In the research on the industrial marketing of green silicon island--Central Taiwan Science Park, Sharon \& Laura (2011) indicated that public infrastructure and transport facilities were necessary for the improvement of investment environment to enhance the investment environment of the park and the neighboring counties and cities and to establish the information market circulation mechanism. Moreover, science parks faced the problem of inadequate resources, which should be improved by Taiwan Power Company maintaining certain power supplied. MarínCatalá (2014) proposed that the public infrastructure of environmental protection technology parks should at least contain land grading and street system, electric power, telecommunication, water supply facilities, natural gas and oil facilities, drainage system parking, sewage farm, waterway system, environmental protection facilities, and ecological landscape engineering (Katz et al., 2012).

5). Financial (capital) resources: Valiña (2011) argued that mid- and long-term financial resource planning of enterprises should focus on fund raising and capital management. Early in 1985, Gitman and Maxwell divided corporate financial activity into 1.Financial Planning and Budgeting, 2.Managing Capital Expenditure, 3.Managing Working Capital, and 4.Raising Long-term Funds. Yoo \& Zhao (2010) regarded "Financial Planning and Budgeting" as the most important activity among the four. An enterprise, in the financial resource activity, should aim to maximize the wealth of shareholders.

6). Government: De Silva (2011) considered that governments should give guidance in the development of products and shorten the science and technology gap for sprouting industries, while developing industry should be rewarded the investment matching with market-oriented function.

\section{RESEARCH DESIGN AND METHOD}

\section{A. Research method}

Fuzzy Delphi Method, proposed by Olaf Helmer et al in 1950, aims to acquire expert consensus and consistent opinions of specific subjects. Nevertheless, small convergence effect often appears in the Delphi Method process, because of different expert opinions, to increase the number of survey times. Besides, means are used for selecting evaluation criteria in Delphi Method, which are easily affected by extreme values statistically. In this case, when the data generation is complicated and time-consuming, the drawbacks of high investment costs, low recovery rate, fuzziness, and distorted expert opinions could easily appear. Fuzzy Delphi Method is therefore utilized in this study for selecting important criteria. It is a kind of expert prediction, formed by some researchers including Fuzzy Theory in Delphi Method, after L.A. Zadeh proposed Fuzzy Theory. In the application, Fuzzy Delphi Method gives up the original algorithm with means but applies geometric mean as the decision-making group to select evaluation criteria. Statistically, it presents the impartiality effect to avoid the influence of extreme values so that the selection of criteria shows the optimal effect.

\section{B. Establishment of evaluation index}

The questionnaire in this study is sent to experts in various domains through email. The first feedback of experts is organized the considerations for enterprises executing social marketing. Such considerations with similar properties are classified into the same category and sent back to experts for opinions. The final consensus is achieved by several runs of enquiries through email. The major categories are set as the key factors in the industrial cluster of agricultural biotechnology parks by calling all experts for the conference. Such key factors are the AHP dimensions, based on which the 
AHP questionnaire is established. With Fuzzy Delphi Method, the evaluation indices in this study are established as following.

1). Human resource: employee skill, manager ability, labor force, and standard working hour

2). Financial resource: bank system, foreign exchange market, and capital market

3). Supportive industry: research institutions, association, and acquisition of raw materials

4). Public infrastructure: transportation, function facilities, R\&D facilities, and sales center

5). Technology and knowledge resource: training institutions, network information service, and technological innovation

6). Government: resource integration, land tax preferences, $\mathrm{R} \& \mathrm{D}$ incentives, and regulation compilation

\section{Research subject}

Through the media reports on agricultural biotechnology parks, experts with deeper understanding of agricultural biotechnology parks are asked the intention of the research through phone calls and then completed the survey through email, facsimile, or mails. Such experts in agricultural biotechnology parks are therefore selected for the analysis. Total 150 copies of questionnaire are distributed and 102 valid copies are retrieved, with the retrieval rate $68 \%$.

\section{RESULT AND DISCUSSION}

\section{A. Result analysis}

1) Level 2 evaluation element in Analytic Hierarchy Process

After the questionnaire survey, the "Level 2" evaluation standard in Analytic Hierarchy Process of key factors in the industrial cluster of agricultural biotechnology parks is acquired. The received data are calculated the geometric mean of relative importance of paired elements to form the Analytic Hierarchy Process matrix. The consistency ratio C.R. $=0.017<$ 0.1 reveals the consistency of the decision-making result in this study. The weight and importance of evaluation elements are sequenced in Table 1, as "technology and knowledge resource", "public infrastructure", "government", "human resource", "financial resource", and "supportive industry".
Table 1: Weights of key success factors in the industrial cluster of agricultural biotechnology parks

\begin{tabular}{|c|l|c|}
\hline $\begin{array}{c}\text { Weight } \\
\text { sequence }\end{array}$ & \multicolumn{2}{|c|}{$\begin{array}{c}\text { Key success factors in the industrial cluster } \\
\text { of agricultural biotechnology parks }\end{array}$} \\
\hline 4 & Human resource & 0.143 \\
\hline 5 & Financial resource & 0.127 \\
\hline 6 & $\begin{array}{l}\text { Supportive } \\
\text { industry }\end{array}$ & 0.106 \\
\hline 2 & $\begin{array}{l}\text { Public } \\
\text { infrastructure }\end{array}$ & 0.214 \\
\hline 1 & $\begin{array}{l}\text { Technology and } \\
\text { knowledge } \\
\text { resource }\end{array}$ \\
\hline 3 & Government & 0.243 \\
\hline
\end{tabular}

2) Overall consistency evaluation of Analytic Hierarchy Process

After completing the weights of all hierarchies, the evaluation indices in hierarchies are distributed based on the relative importance, showing the importance of indices in the entire evaluation system. The overall weight of the industrial cluster of agricultural biotechnology parks is also generated, Table 2. The result presents the top 5 indices, among 21 evaluation indices, as technological innovation, R\&D facilities, training institutions, network information service, and $R \& D$ incentives.

Table 2: Overall weight of the industrial cluster of agricultural biotechnology parks

\begin{tabular}{|c|c|c|c|}
\hline Dimension & Index & $\begin{array}{c}\text { Overall } \\
\text { weight }\end{array}$ & $\begin{array}{c}\text { Overall } \\
\text { sequence }\end{array}$ \\
\hline \multirow{4}{*}{ Human resource } & Employee skill & 0.048 & 11 \\
\hline & Manager ability & 0.063 & 6 \\
\hline & Labor force & 0.039 & 13 \\
\hline & Standard working hour & 0.018 & 19 \\
\hline \multirow{3}{*}{$\begin{array}{l}\text { Financial } \\
\text { resource }\end{array}$} & Bank system & 0.035 & 14 \\
\hline & Foreign exchange market & 0.034 & 15 \\
\hline & Capital market & 0.045 & 12 \\
\hline \multirow{3}{*}{$\begin{array}{l}\text { Supportive } \\
\text { industry }\end{array}$} & Research institutions & 0.027 & 17 \\
\hline & Association & 0.006 & 21 \\
\hline & Acquisition of raw materials & 0.011 & 20 \\
\hline \multirow{4}{*}{$\begin{array}{l}\text { Public } \\
\text { infrastructure }\end{array}$} & Transportation & 0.056 & 8 \\
\hline & Function facilities & 0.030 & 16 \\
\hline & R\&D facilities & 0.086 & 2 \\
\hline & Sales center & 0.023 & 18 \\
\hline \multirow{3}{*}{$\begin{array}{l}\text { Technology and } \\
\text { knowledge } \\
\text { resource }\end{array}$} & Training institutions & 0.078 & 3 \\
\hline & Network information service & 0.075 & 4 \\
\hline & Technological innovation & 0.096 & 1 \\
\hline \multirow{4}{*}{ Government } & Resource integration & 0.053 & 9 \\
\hline & Land tax preferences & 0.058 & 7 \\
\hline & R\&D incentives & 0.071 & 5 \\
\hline & Regulation compilation & 0.050 & 10 \\
\hline
\end{tabular}




\section{Conclusion}

By organizing the overall weight of evaluation indices of key success factors in the industrial cluster of agricultural biotechnology parks, it is summarized as below.

A. Under human resource, the evaluation indices are sequenced manager ability, employee skill, labor force, and standard working hour.

B. Under financial resource, the evaluation indices are sequenced capital market, bank system, and foreign exchange market.

C. Under supportive industry, the evaluation indices are sequenced research institutions, acquisition of raw materials, and association.

D. Under public infrastructure, the evaluation indices are sequenced R\&D facilities, transportation, function facilities, and sales center.

E. Under technology and knowledge resource, the evaluation indices are sequenced technological innovation, training institutions, and network information service.

F. Under government, the evaluation indices are sequenced R\&D incentives, land tax preferences, resource integration, and regulation compilation.

From above analyses, technology and knowledge resource is the primary problem requiring for the solution from the park administration. It also reflects the characteristics of high threshold of industrial technology and time-consuming of products from $R \& D$ to listing. In terms of the primary key success factor "technological innovation" in the industrial cluster of agricultural biotechnology parks, the combination or strategic cooperation of tradition and technology is critical for agricultural enterprises, including the transforming ones, because any enterprises with unsuccessful transformation might close down. The park administration should emphasize the high-level investment environment offered by a perfect public infrastructure, after concerning about technology and knowledge resources. Especially, R\&D facilities provide better service of "Innovation Incubation Center" for the cultivation of enterprises and could reduce the worry of fund raising for such enterprises concentrating the limited resources on the professional field in the beginning of businesses. Park administration should reinforce the functions of academic and research institutions, such as combining relevant institutions, association, industrial association, agribusiness training institutions, academic research institutions, and school teachers, manpower, equipment, and place, to systematically assist small and medium enterprises making various employee training measures.

\section{Recommendations}

According to the empirical results, the following conclusions are proposed, expecting to offer definite guidance and directions for the industrial cluster of agricultural biotechnology parks.

A. Reinforce public infrastructure and build the operation space for sustainable development.
Domestic technology parks have actively collected opinions, intending to create the parks conforming to the "green environment" with "production", "life", and "ecology". Nonetheless, the formation of industrial clusters would induce inadequate living function facilities, in regard to public infrastructure. Besides, from the development plan zoning ordinance, the functional life facilities and life-related facilities neighboring agricultural biotechnology parks are insufficient. Such inconvenient and insufficient life function would affect senior technical personnel's intention to invest in parks. Park administration should cooperate with local government to properly plan surrounding land for narrow purpose; or, once buildings are randomly constructed on farms, it would become the worry for the future development of agricultural technology.

B. Incentives to encourage R\&D of enterprises

In addition to specific technology projects, the government should irregularly examine the $R \& D$ performance of firms in parks with rewards and grant enterprises to promote $R \& D$ alliance in order to drive the R\&D trend. Council of Agriculture, Executive Yuan, should develop the ability of resource integration and efficiency, extend the $R \& D$ energy of $R \& D$ units to agricultural biotechnology parks, and implement $R \& D$ results to practically help the enterprises stationed in parks.

C. Reinforce the creation of tourism promotion characteristics different from other parks to match with tourism focus

Agriculture biotechnology industry is essentially different from electronic information industry. It requires a long time for the products from $\mathrm{R} \& \mathrm{D}$ to mass production that the management model cannot be compared with electronic industry centered technology parks. Under the premise of $R \& D$, inserting industrial tourism and allowing firms satisfying the marketing through tourism industry to acquire sources of capital could create new cluster markets for agricultural biotechnology parks.

\section{References}

[1] ASCHE, F. ;BJORNDAL, T. The economics of salmon aquaculture . Sussex : John Wiley and Sons, 2011.

[2] ALVIAL A. The Recovery of the Chilean Salmon Industry: The ISA crisis and its consequences and lessons. Puerto Montt, Chile: World Bank (2012).

[3] ANTONELli, C.; PATRUCCO, P. ; QUATRARO, F. Productivity Growth and Pecuniary Knowledge Externalities: An Empirical Analysis of Agglomeration Economies in European Regions, Economic Geography, v.87, p 23-50, 2011.

[4] HSUEH, Y. H. ; TSENG, H. Y. Exploring the Clustering Location of Accommodation Units Through the Tourism Development in the Cing-Jing area of Taiwan. International Journal of Basic and Applied Sciences, v.13, p 34-43,2013.

[5] IIZUKA M.; GEBREEYESUS,M. A Systemic Perspective in Understanding the Successful Emergence of Nontraditional Exports: 
Two Cases from Africa and Latin America. Maastricht : United Nations University, Maastricht Economic and social Research institute on Innovation and Technology, 2012.

[6] KATZ, J.; IIZUKA, M. ; MUNOZ S.. Creciendo en base a los recursosnaturales, tragedias de los comunes y el futuro de la industriasalmonerachilena. Santiago de Chile: United Nations, 2011.

[7] KATZ, J.; IIZUKA, M.M..Natural Resource Industries, "Tragedy of the Commons" and the Case of Chilean Salmon Farming. International Journal of Institutions and Economies. v.3, p. 259-286, 2011.

[8] KATZ, J.; IIZUKA, M. Globalization and the Changing Institution for Sustainability: The Case of the Salmon Farming Industry in Chile. Maastricht : United Nations University, Economic and social Research institute on Innovation and Technology,2012.

[9] KONG, L. Improbable Art: The Creative Economy and Sustainable Cluster Development in a Hong Kong Industrial District, Eurasian Geography and Economics, v.52; p.182-196, 2012.

[10] LAI, Y. L.; HSU, M. S.; LIN, F.J.; CHEN, Y. M. ; MAW, S. H..The Effects of Industry Cluster Knowledge Management on Innovation Performance. Journal of Business Research, v.67, p.734-739, 2014.

[11] LERNOUD, J. ; WILLER, H. The world of organic agriculture statistics \& emerging trends 2014. Research Institute of Organic Agriculture(FiBL)\& International Federation of Organic Agriculture Movements, 2014.
[12] MARÍN CATALÁ; B. S.. Análisis de la situacióndelturismo de negocios en la ciudad de Valencia. Valencia: Thesis doctoral, Universidad Politécnica de Valencia, 2014.

[13] NAVARRO, M. V.. Análisis del gastodiario de los turistas de negocios: duración de la estancia y categoríaprofesional. Cartagena: Trabajo fin de Master, Universidad Politécnica de Cartagena, facultad de ciencias de la empresa, 2011.

[14] NUTRECO. How can aquaculture contribute to feeding 9 billion people in 2050 in a sustainable way? Amersfoort, The Netherlands: Nutreco Publication, January, 2011.

[15] ROYNE, F.; BERLIN,J.; RINGSTROM, E. (2015). Life Cycle Perspective in EnvironmentalStrategy Development on the Industry Cluster Level: A Case Study of Five Chemical Companies. Journal of Cleaner Production, v. 86, p.125-131.

[16] SHARON, Z.; LAURA, B.. The Life Cycle of New York's Creative Districts: Reflectionson the Unanticipated Consequences of Unplanned Cultural Zones. City, Culture and Society, v.2, p.131-140, 2011.

[17] VALIÑA, M. Á.. Turismo industrial: el casoalemán. ROTUR: Revista de Ocio y Turismo, v.4, p. 117-138, 2011.

[18] YOO, J. J.; ZHAO, X. Revisiting Determinants of Convention Participation Decision Making. Journal of Travel \& Tourism Marketing, v.27, p. 179-192, 2010. 